\title{
Many centers: suburban habitus
}

\author{
David Kolb
}

New patterns of suburban development in America after 1945 offered space for modes of life different from the social habits of those moving from crowded cities. Over time those habits changed, and then they kept on changing as new kinds of networks developed, so that now much of the built pattern of suburbia lags bebind social activities and roles. What happens when so many connections in suburban life become electronic rather than spatial? This paper recalls two kinds of suburbs, discusses the mutual interaction of social roles and spatial patterns, then the polycentric habitus that has increasingly replaced hierarchical oppositions of center to periphery, in spatial planning, in organization structures and in modes of knowing. This is liberating but also surveyed by panoptic observers. These cannot be completely evaded, but openness in the interplay of architecture and social norms can lead to unexpected social formations and local creativity. Suburbia is evolving in ways that will better express and inculcate a polycentric habitus that it helped create.

Key words: suburbs, suburbia, sprawl, land use, habitus, networks, panopticon, Internet, city

Garden cities of the past

W hen I was growing up in the 1950 s 'everyone knew' that the Long Island town where I lived was economically better off than the towns on either side, but not so well off as the towns with big estates north of us. Although there were distinctions to be made among different neighborhoods within our town-we lived in a 'poorer' section, with smaller houses built in the 1930s-all our neighborhoods were better off than those in the next towns over. You could tell from the houses, as well as from what stores were in the different town centers. These older railroad suburbs had been built each with their own train station and downtown district. In our part of Long Island there was no space between towns. You crossed a street and the jurisdiction changed, as did the house sizes and styles. Separate school systems and church parishes, with their differential loyalties, reinforced distinctions. When asked where you were from, you answered with the name of your town. Growing up in this built environment, we learned to read housing and stores for class and racial status. We knew whether or not 'people like us' inhabited a given area. The town plans and house types showed and taught us who we were, how to act and where we fit in the social hierarchy (Figure 1).

We learned to read housing styles. This house was Spanish, that one was Colonial, that other was Cape Cod, and so on. In my neighborhood there were seven or so styles, though there were fewer floor plans. What was important was that a house have one of the standard styles. Living in such a house told the owners where they stood. 


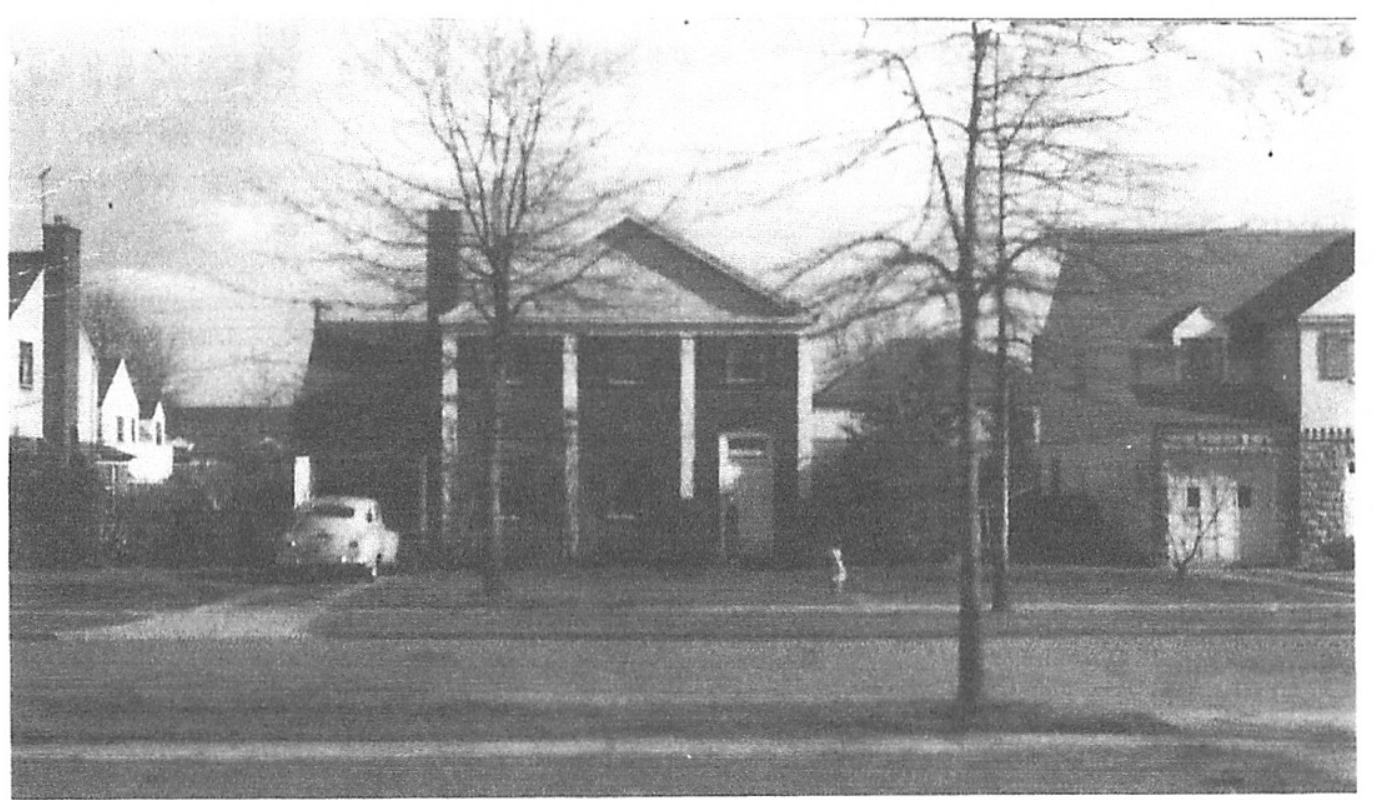

Figure 1 The author's house and neighborhood, with similar floor plans wrapped in historical styles (1949 photo by Harry Kolb).

In a small unpublished project some years ago, Tomas Wikström and I compared newspaper real estate advertisements in Sweden and the USA. ${ }^{1}$ What had been striking to me was the absence in Sweden of references to the style of the house or apartment being advertised. In part this was because there is less stylistic variation among dwellings in Sweden (though there is more variation in vacation homes). But in the USA, it was important to notify people that a house had some historical style from the customary palette. Domestic architecture in the stripped-down modernist style common in Sweden often signified in the USA poverty and government-built housing (though a large house in a severe modernist style could signify riches and daring taste) (Figure 2). ${ }^{2}$

It was the presence of one of the standard historical styles, though not of any particular style, that we noticed when I was growing up. Except as a matter of personal taste, whether a house had a Colonial as opposed to a Federal style made little difference, but it was important that it have some historical style. This showed that the family was not among that class of people who could only afford plain public housing or whatever bland style low-end developers had chosen to reproduce.

The palette of historical styles that were 'normal' changed over time but it did not include all historical references. More wealthy people could choose to build in styles beyond the fuzzy borders of the standard palette, for instance, a Moroccan or Japanese or extreme modernist style.

Besides house style, other distinctions came into play, such as the size of the house and lot, the degree of care bestowed on the lawn, play equipment for children, and other visible factors, to help us read the landscape (Figure 3). There was a nice fit between our expectations and roles and the built environment. ${ }^{3}$ Besides status hierarchies, my suburban environment was organized according to a geographical hierarchy. I grew up thinking that commuting to a big city center was what people above a certain class did for work. I took for granted that residential areas had uniform populations divided by income and ethnicity and race. I didn't expect to find in 


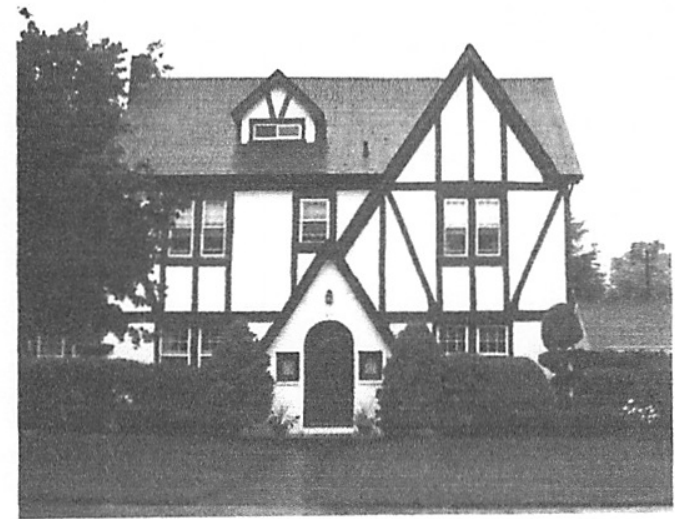

Figure 2 A still larger house in the author's fown with stronger status indicators (2008 photo by Elizabeth Colucci).

the suburbs important cultural or medical facilities, nor speciality shopping and ethnic restaurants, nor glitter and excitement. Those were located in The City, an hour's railroad ride away. I expected general social order within a fixed framework of classes, civilized arguments and fierce sports rivalries. I never felt that I was surrounded by like-minded people, since a town, no matter how homo- geneous it really is, generates its own internal differences, and besides those, we distinguished ourselves from New York City dwellers and from other suburbs. But in fact my town was very homogeneous, and I didn't know about the real estate tactics used to discourage diversity.

Anthropologists are fond of citing the legible landscapes of 'primitive' villages where the layout of the houses and the details of their architecture correlate with and inculcate social roles and cosmological views (see, for example, Bourdieu, 1977). A medieval village surrounding its church shows the same fit between social and spatial patterns. In the city-and-suburb centralized hierarchy I grew up in the positioning and the details of the architecture also spoke about and reinforced social roles and indicated who held economic and cultural capital. A map of status could be read in the New York area with its city core of towering office buildings and festive consumption zones, its residential districts old and new, its industrial districts and slums, surrounded in turn by gentrifying areas and economically
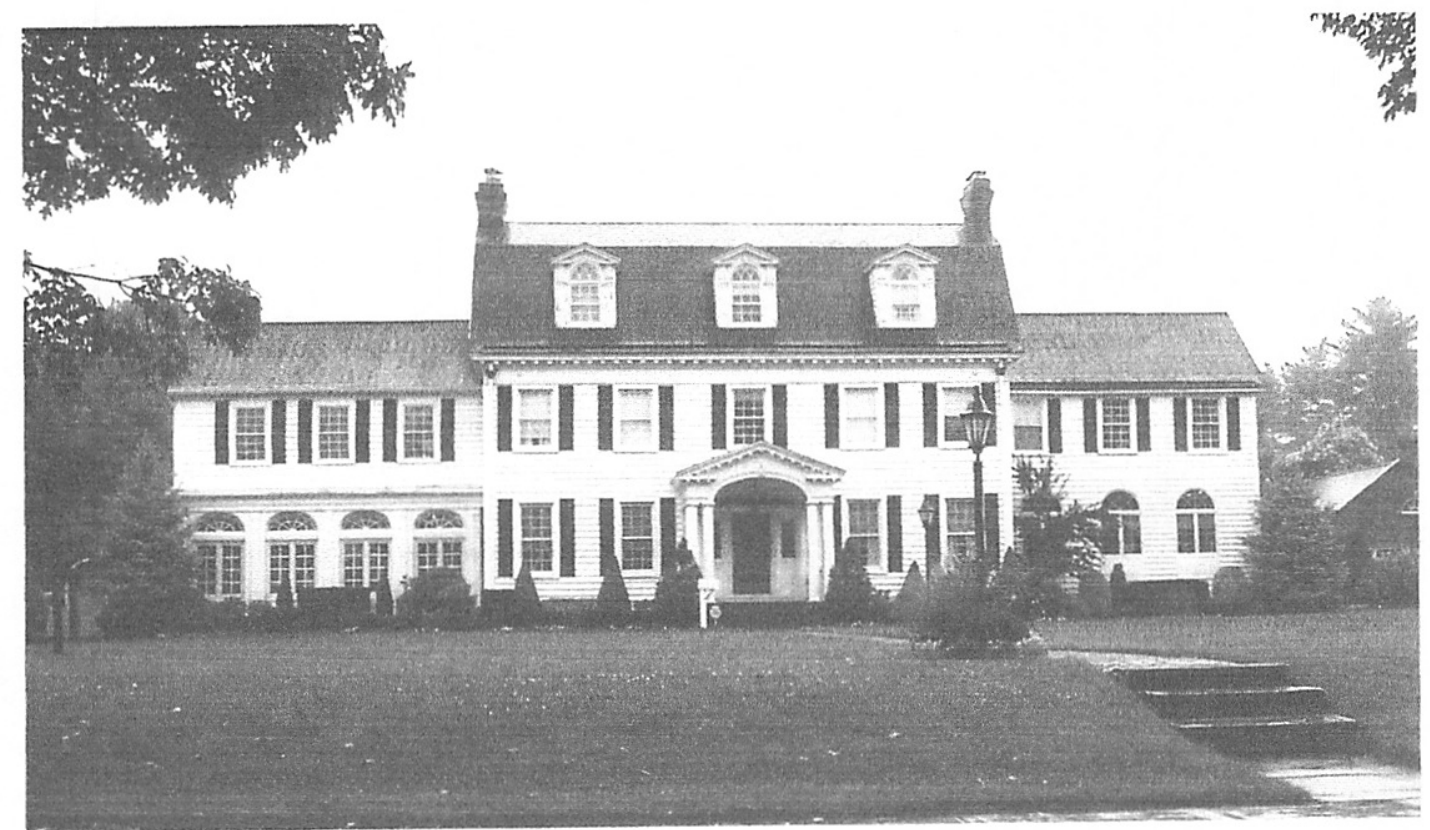

Figure 3 A much larger house in the same town, with a loud status message (2008 photo by Elizabeth Colucci). 
differentiated suburbs. Because Long Island was connected to the mainland only through bridges and tunnels in New York City, it was both symbolically and literally true that everything went through the center and was referred to it. Besides the bridges and tunnels there were two ferry lines that crossed Long Island Sound to Connecticut, but these departed from far out in the then rural part of the island, so they did not enter our plans except in unusual cases.

\section{Garden cities of the present}

This clear spatial/social correlation and hierarchy gradually lost definition. In the 1950s rural Long Island to the east of us was filling in with a new kind of suburb. On the scale of individual houses there were uniform bland patterns and only small personalizations. ${ }^{4}$ House and lot size might differentiate one large tract of development from another.

Spatial hierarchy began to disappear. Major roads multiplied and tended to look like each other. Commercial strips blended into one another without the distinctiveness that different town centers once possessed. New office and industrial buildings appeared in scattered locations. Often you could not tell them from one another unless the corporation had paid for exceptional architecture, but the most distinctive complexes were often hidden behind berms or trees. As the offices and workplaces appeared here and there, the centralized travel patterns disintegrated. In my older suburb most working people (men) commuted to New York on the railroad or had professional jobs in nearby towns. Now suburban jobs take people in any and all directions to work sites scattered without any clear plan, with the automobile the only common factor, except for the telecommuters. It's no longer evident in what direction people 'should' or 'do' go for work or even whether they go anywhere: there is no economic reference center for work.

On the town scale, the new suburbs lacked the centralized structures of the older railroad suburbs. They had no real town centers, though retail strip malls were scattered about. Larger malls could be ranked by how upscale their stores reached. Still, one mall looks much like another despite struggles to be different. Really high-end malls can be distinctive, signaled by smaller parking lots, less garish signage. But even this distinction fades as high-end chains repeat themselves.

On the regional level the division of functions into residential, commercial, industrial and office space still spoke of standard modern planning and of large institutions providing replicated services. But there was less and less differential significance attached to where these functions were located, with no overall pattern except what resulted from the history of highway building and the gambles of developers.

The suburbs have become less legible. The suburban house has become more and more enmeshed in a decentered network of relations and connections and transportation in all directions. A house has become harder to read, because the population of suburbia has become more diverse while the housing stock has remained largely the same. The uniformity of suburban houses has become something of a surface illusion. Behind the façades there may be people of different ethnic and racial groups, non-traditional families, and a wider range of economic and social classes, invisible unless the practices of some ethnic group impact the look of the lawn or the equipment available in the backyard. You can no longer be sure, looking at a well-maintained suburban house, what kind of 'people like us' live there.

These changes emphasize what has always been true, that the units that signify are not the buildings alone but the buildings plus the network of norms and connections which define their position in society and their use from day to day. Architecture and its details certainly have their effects on the meaning intertwined with the building, but similar architecture in similar locations may have very different impacts depending upon people's communication, social and transpor- 
tation network connections and the forms of life they enable. Suburban tracts, or individwal houses, may look identical but can be very differently situated in the overall networks, and so provide very different meanings and teach different values and roles to those caught up in their net of relations. ${ }^{5}$

\section{Spaces and social patterns through time}

Buildings have a way of outlasting their original uses, and social networks change. since individuals and communities can alter while the architectural object remains, it is empting to see the meaning of the architecure as resulting from a mobile, active social iubjectivity bestowing significance on an mmobile, passive material object. But there $s$ no passive architectural object receiving neaning from an active social or individual iubjectivity. The two form and inform each ther. (On the other hand, and for the same 'eason, a building or city plan cannot become in overpowering cultural device that shapes assive receptive selves.)

A building's reality involves more than its hysical materials; its use is part of its being. $\mathrm{A}$ building is not fully definite and meaningul until it is enmeshed in networks of activty, but it is also true that networks of neaning and activity are not fully definite intil they are anchored in space and architecure. That embodiment inflects meanings; :ome physical arrangements harmonize well with the activities assigned them; some do 1ot, and some suggest new practices and iocial roles. The social network and the buildngs become definite together and change one inother.

For example, when Christian worship in he Western Roman Empire adopted a stanlard Roman public building form (the basilca) for its houses of worship, the long and elatively narrow shape (originally designed o accommodate multiple meeting places long a central spine with side rooms) mposed a linear form on the worshiping ommunity, facing the front where the leaders presided. An increasingly hierarchical church institution adapted and was influenced by this architectural plan. Or consider the changes in modes of life that led to and were made possible by the introduction of individual bedrooms for middle-class dwellings in the late Middle Ages and Renaissance. Or the social and architectural factors motivating the American middle-class resistance to the modern free plan in house design, and then the gradual weakening of that resistance. Or, again, the way that a complex interplay of economic motives, environmental threats, technological changes and competitive pressures brought about the expansion of suburban homes toward their lot lines, leading to the suburban McMansion with almost no front or back yard. This was a significant change in suburban ideal patterns of life and family activity, and it was both made possible by and itself accelerated changes in architectural space. ${ }^{6}$

Buildings and selves exist in time, and as social meanings and architectural patterns are carried forward they are reread as they find themselves in new contexts. What seemed a complete set of social roles and values may seem one-sided as contexts grow. In the time of globalization, when what was far away suddenly arrives next door, society is invaded by foreign images and bodily behaviors and building types. What had been asserted to be The Center can suddenly appear as one node among many.

While they take on definite meaning together, buildings and society can each exceed the other: there are more possible social lives, roles and values than those embodied in a given architectural setting, but also architectural spaces can suggest possibilities for action and connection other than those currently defined by society. Over time even the most dominating building or city plan will be used in ways that deviate from today's patterns. Even the most tightly controlled and supervised physical space will provide corners for illegalities. Meaningful spaces create and are created by, but also can slip away from, social patterns. 


\section{Polycentric habitus}

People who moved from the cities to the newer suburbs after World War II found different spaces that offered more room and more privacy than the crowded immigrantfilled city that many people were being encouraged to leave (Figure 4). Banking and tax policies were devised to favor greenfield construction over repair of older cities, separating races and classes and favoring suburban real estate and financial interests (see Boden and Molotch, 1994). But this new suburbia also broke the traditional hierarchical organization of space and activity. There were no clear town centers, the City was more distant, and more and more jobs moved out into an increasingly polycentric sprawl (Sudjic, 1992; Fishman, 1997). The built environment was leveling out; malls here and there brought people together but did not provide centralized public spaces (Boden and Molotch, 1994).

For a brief while as the new tract suburbs sprang up the possibilities opened by the new architecture and spatial layouts were ahead of their social patterns, which lagged behind. But then, as people lived in the new suburbs, and the center cities lost their economic and industrial primacy, new social roles and patterns developed. As elaborate but less hierarchical networks for transportation and communication and data brought a greater variety of connections, and as diverse populations moved to the suburbs, suburban architecture and layout began to lag behind the social changes. The single-family house continues to dominate suburbia even as families redefine themselves, so while suburban architectural form still images traditional family roles and patterns of work, those are less and less common in the diverse and multiply centered lives of its inhabitants.

What does it mean to multiply centers? When I was growing up, the older railroad suburbs fitted in with, expressed and inculcated in their layout and architecture a general habitus. That habitus embodied ways of moving and holding one's self that expressed and promoted hierarchically nested oppositions of center to periphery. In fields as diverse as governance, urban planning, corporate structure, finance, education, manufacturing, family life, in thought and in personalities, order meant centering and clear subordinations. Cities and towns were built

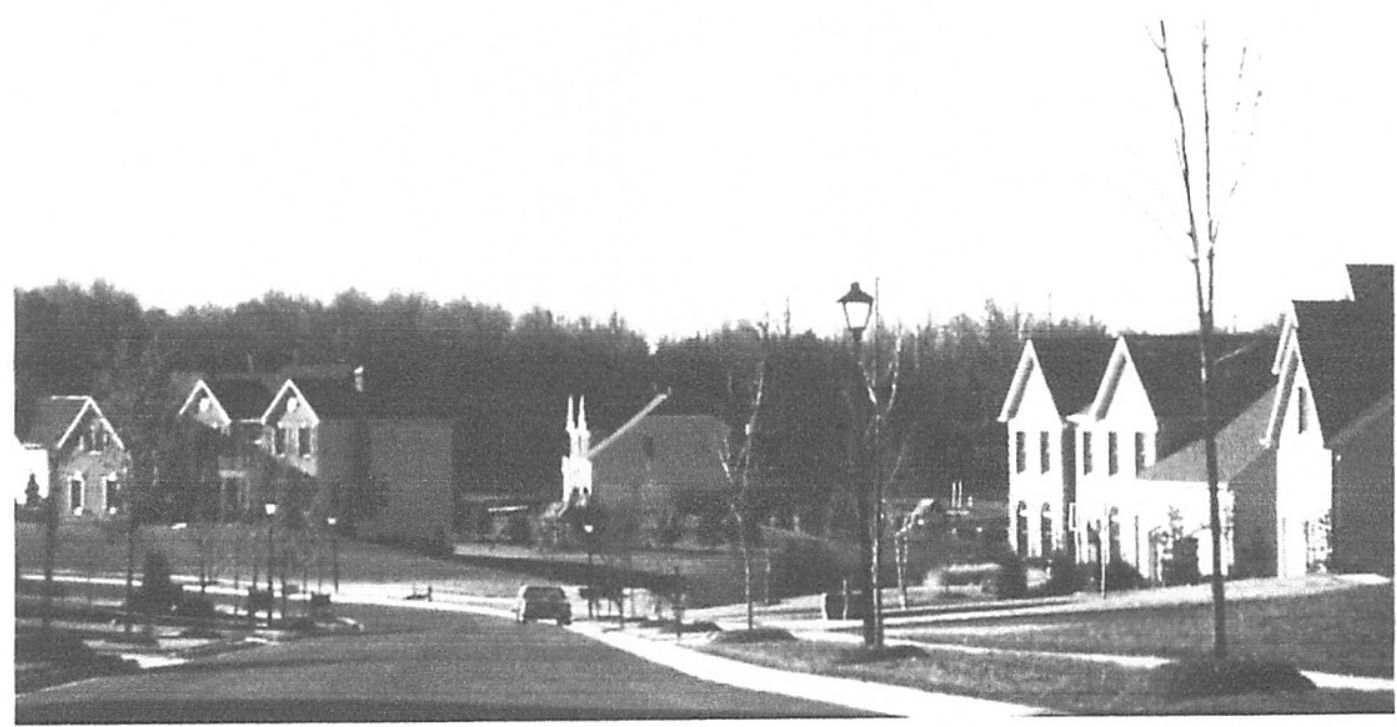

Figure 4 New suburban houses near Washington, DC (1999 photo by David Kolb). 
that way, curricula and knowledge were organized that way, organizations acted that way. That habitus has been altering in recent decades as polycentric and complexly networked patterns have emerged in all fields. A graph showing a person's or a town's connections would now be less like a tree opening out from a central node that must be traversed to reach other regions. Relations can spread and link without passing through hierarchically dominant Centers.

The polycentric habitus holds bodies and minds differently. It does not expect or impose hierarchy and centers. It can be found in the spatial organization of the suburbs, with their Edge Cities and scattered workplaces and malls. It can be found in the way information is stored, in new interdisciplinary curricula, in flattened organizational structures. The built environment no longer offers a centralized message nor enforces a hierarchical set of connections. The growing habitus does not valorize central clearinghouses and single authorities, nor look for space or people or information or organizations to be arrayed around a compelling mega-center. In the organization of knowledge a hierarchically indexed file system is replaced for the user by a heap of data and a search engine. Flattening the hierarchies of knowledge and information goes along with flattening hierarchies in business organizations, for whom suburbia has already provided a decentered space. ${ }^{8}$ This flattened world is tied together by more and more kinds of connections and links and communications and networks. These go beyond what the built environment of suburbia can express, as connections multiply and similar looking suburban areas or houses participate in very different networks.

These new connections and networks are strung out on increasingly abstract grids. The New York City Commissioners' Plan of 1811 extended over Manhattan a grid of future streets long before most of the island was inhabited. The grid regimented space for future activities and guided real estate speculation. Over time, central regions developed in Midtown and Lower Manhat. original grid's abstract form did not .

Roman central square. Because of its al regularity, despite seeming rigid a $s$ provides a framework for multiple centers tc develop wherever they seem useful to various interests.

Extended across the continent by the Rectangular Survey (Hubbard, 2009), then realized in straight and twisty road patterns, the grid has now become even more abstract. The GPS unit in your cell phone or car can guide you to locations specified by latitude and longitude. That grid has no preferred direction or center, and the GPS does not require you to consult an overview map. Places become available in ways that allow local centers to develop, but the grid and the GPS also allow places far from any centers to be accessible even as they maintain their distance.

\section{Polycentric panopticons}

All this liberates us from hierarchical and centered spatial patterns, so it might also seem to liberate us from hierarchical power relations. We can be scattered and mobile yet connected, so we cannot be surveyed from a big Center. Unfortunately, surveillance no longer needs a big Center.

While the new habitus looks for horizontal connections and wide horizons, emerging from the shadow of The Center does not bring some magical freedom. Foucault talks about the bio-power that has no center yet extends its filaments everywhere, producing the disciplinary effects of the panopticon without the need for a central observing tower (Foucault, 1979). But in our new connected world there also exist real panoptic towers where people and machines observe us. Marx said capitalist markets produce monopolies because the ideal of free trade plus the search for profit encourages tactics that restrict free trade. Similarly, we might say that decentered horizontal connectivity plus the search for profit produces panopticons. 
For example, the Internet brings more freedom of connection, leveling accesses, decentering and disintermediating networks. But this freedom is being watched. Microsoft won the browser war, for a time, but that no longer matters. The browser is no longer the only portal to the Internet. While there are more webpages than ever, the power of the app is growing. Apps are small specialized programs, often on mobile devices, which do not display webpages but rather gather information from databases and repositories. 'There is an app for that', as the ads say. The web browser is still important but in daily life omnipresent small apps get you more useful information more quickly. What time is the movie? Does the restaurant take reservations? Is there a train soon? Where are we? What is the weather forecast? What team won in 1986? There are no webpages being consulted in these inquiries; apps consult decentralized databases to help with a myriad of small decisions in daily life away from big computers and web browsers.

Most important for my point, however, is that with apps, as with web browsers, the communication goes both ways. As I find out information, each site, Amazon, the New York Times, Google, etc., records my searches and builds a picture of me in the myriad decisions of my daily life. Each site becomes what Bruno Latour calls an Oligopticon, knowing a great deal about a narrow slice of my life (Latour, 1998; Latour and Hermant, 2006). 'Oligoi' is ancient Greek for 'a few' (as in oligopoly or oligarchy); I have used the English plural for 'oligopticons' and 'panopticons' instead of the Latour's Greek plurals 'oligoptica' and 'panoptica'. But unlike the oligopticons Latour discusses (the room that integrates traffic information from the Paris Périphérique, another for water and sewage throughout the city, and so on) these narrow slices of my shopping, Internet behavior and travel can and are being combined; over time they become salable commodities traded among those who want to target advertising.
That information can find governmental uses, as well.

It might seem that the Internet with its ability to route around blockage and attempted monopolies should provide an escape from surveillance. Skilled navigators may indeed be able to anonymize themselves and some of their traffic. But the average user most of the time is noted by panoptic corporate entities who sell information to one other. Google currently stands as the top information collector but it is far from the only one (Figure 5). Social network sites like Facebook collect enormous amounts of more personalized information and their business models intend to monetize that resource.

To keep track of the usage of a large website that discusses the notion of 'place' and suburbia, I registered it with Google Analytics, which collects and displays an astounding variety of information about visitors: their Internet domains, time on site, which pages they visit, which search terms brought them, how long on average each page on the site was read, and so on. Similarly, at the time that I am writing this (autumn 2010), the media are hyping up a dispute between Apple and Google over the iPhone vs. Android, and over their rival systems for delivering advertising to apps on mobile devices. The unspoken issue is who will gather and control the information gained from individuals' use of mobile devices.

So the oligopticons multiply and talk to one another, approaching a panoptic view. Nor do they all need the Internet. Pay your road toll with an EZPass and a database records your position and time. Buy an airline ticket, use your credit card, make a cell phone call, and you are noted. Walk down the street, and your image is stored on cameras, where face recognition software can find you. Commercial enterprises have an interest in you, and the government looks on. In the long run, less dense suburban spatial arrangements might be more open to an individualized surveillance that was never practical in dense crowded cities. 


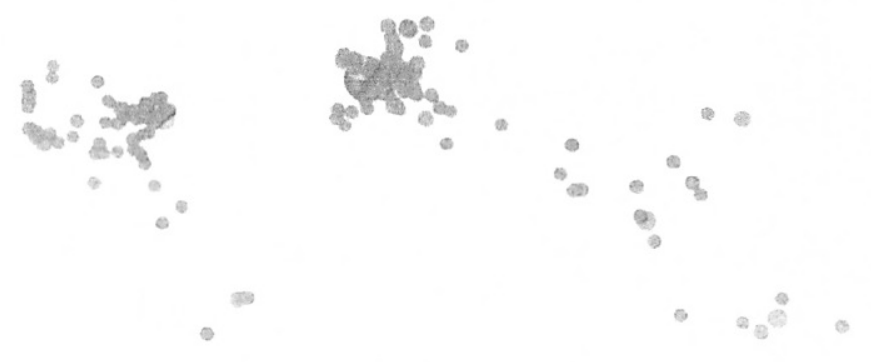

Figure 5 Google Analytics list of the cities from which people viewed the Sprawling Places website in 2009-10.

One might argue that this is relatively harmless. The assembled information does not enforce the bodily uniformity of the Prussian army. It is mostly used (so far) to craft personalized ads; they want to sell us things. We are not obliged to buy, so our choices are not dominated. But this is a shortsighted objection. It is true that choices are available, but they have been sculpted. Advertising defines the available options. It makes some options visible and it makes others invisible, especially options that might threaten the system (Slee, 2006). And even if one 'never looks at the ads', images and alternatives still shape unconscious ideals of bodily perfection and social success. These can be fought against, but it is a constant struggle. Furthermore, the polycentric habitus expecting linkage and open horizons is frustrated by the controlled supervision of the links available. What should be an open exploration becomes a choice among brands. There is also the continual distraction nibbling away at what should be free connections and self-created syntheses.' Nonetheless, despite whatever degree of surveillance and pressure is practical, space and language refuse to be completely disciplined. Just as language can always be used by poets and innovators in ways that exceed its current rules, so too there is no way to limit new uses of buildings and town plans. Architecture and planning always inculcate ways of holding and moving our bodies, and assign spaces for social roles. But the same stubborn factuality that allows architectural form to lag social roles also allows it to exceed them. Physical space always offers more possibilities for activity than any set of social roles can define. ${ }^{10}$ Buildings and layouts can be reread in surprising ways, and space opens more possibilities for movement than the current social grammar dictates for its use. Dense city spaces encourage unforeseen encounters that breed innovation (Sassen, 1991). Dense but spatially noncontiguous connections in the suburbs can do the same. Castells (2004) stresses the importance of activating such possibilities and developing counter-networks that move beyond panoptic surveyability. ${ }^{1}$ In suburbs, just as in dense cities, networks and counternetworks will multiply, for good and bad (Figure 6). 


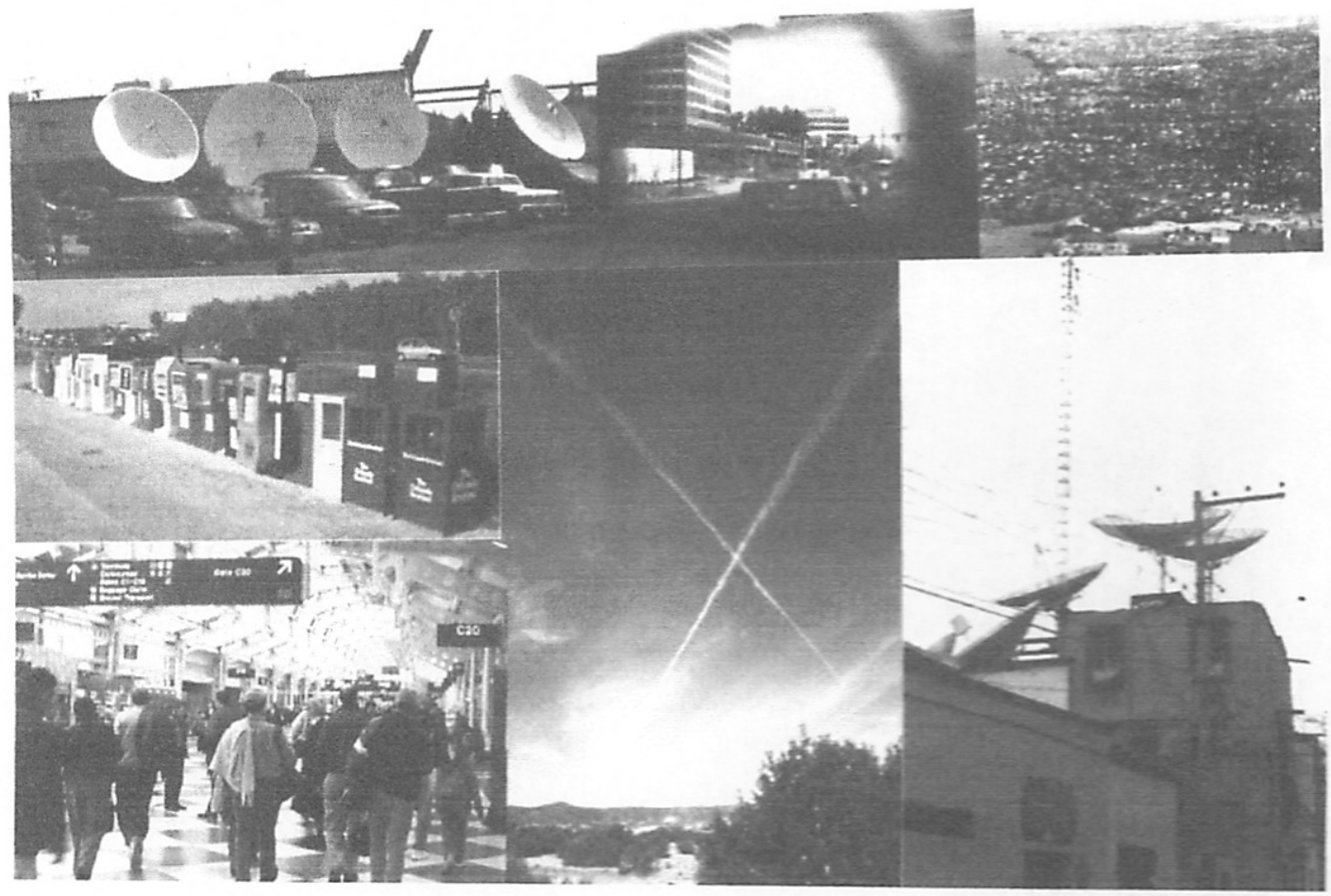

Figure 6 A montage of suburban network connections (1999-2003 photos by David Kolb).

\section{Suburban lags and advances}

The way all transport had to pass through the New York City of my youth could be a metaphor for the way in which almost all kinds of transactions and connections were hierarchically centered. But that topology has changed. The Internet can link anyplace to any other place. There are huge server farms, DNS servers and chokepoints on the Internet as a physical system, but these are invisible and replaceable in a way that New York City was not. GPS reckoning allows one to deliver goods to any point. So smaller local nodes can multiply.

As mentioned above, when World War II veterans and others moved to the new tract house suburbs after the war, they brought city habits and modes of life to the possibilities offered by open suburban spaces and new single-family houses. In effect, social patterns lagged behind architecture and land use. But quickly a suburban mode of living evolved that took advantage of the new possibilities. Over time both the layout and the social patterns of suburbia continued to change. The changes came about in part because new populations and new family patterns arrived in the suburbs, and also because of the growing dispersion of workplaces plus new networks and transport corridors that were no longer only radial to and from the city. These changes began to embody and inculcate a polycentric habitus. But housing patterns lag behind.

All those separated single-family homes with no local commercial or service centers nearby lag behind social patterns that emphasize linkage and multiple temporary groups. Housing patterns in suburbia resist change because their massive built presence on the land makes rebuilding (as opposed to piecemeal additions) difficult and expensive. In addition, concerns about the safety and value of houses encourages laws and zoning regulations that make it difficult to alter the distribution of land and dwellings. Watchful neighborhood associations and 
landowner groups work to prevent change that might lessen property values. It is difficult in most suburbs to get permission to build townhouses or multifamily dwellings. As a result, suburban architecture and spatial patterns have become divided into a more conservative housing sector and the more polycentric, dispersed work and commercial sectors. Yet even in this situation new kinds of families and new kinds of living patterns are occupying traditional single-family homes, and in the current real estate slump there seems to be more flexibility for the reuse of property than had been the case before.

On the other hand, commercial buildings, which are constructed to last a shorter time and are more rapidly depreciated, can provide more opportunities for change. Small local nodes are created or strengthened where commercial buildings are reused. Old malls take on new identities as schools, community centers or housing. Failed big boxes are becoming churches, schools and libraries. ${ }^{12}$

One factor that will encourage the creation of highly connected local nodes is rising energy costs. Whether one agrees with the peak oil prophets of doom or with those who think that alternative energy sources will prevail, in either case energy costs will rise, this will encourage the creation of multiple and denser local centers. Such nodes, spatially separated but linked by communication and transport networks, will strengthen and better inscribe the polycentric habitus on the ground, as they show and teach both less overall hierarchy than the old railroad suburbs, and less shapeless dispersion then the standard tract suburbs. Such innovations will increase the resources available to suburban residents, who need still more local nodes if they are to strengthen the polycentric habitus that they themselves helped create.

\section{Notes}

1 My thanks to Tomas Wikström for helpful comments on an earlier version of this paper. Wikström illustrates and discusses our changing urban and suburban life through images at hitp:// tomaswikstrom.nu/ and a blog at http:// ptomasw.wordpress.com/. He rightly points out that the word suburb (and its Swedish equivalent förort) has become misleading as the 'urban landscape' loses its dominant centers.

2 The highest social status and wealth can confer invisibility. The very richest people may not live in publicly splashy houses but behind walls or up unassuming driveways to large pieces of land that are invisible but not obviously so. Their invisibility is itself hidden.

3 Both in the towns and further out in rural long Island the clues for class and race were crosscut by divisions according to good and bad taste, so a big house could be in bad taste. Different tastes had their own class and racial modes.

4 In the first Levittown, on Long Island, residents were forbidden to add on to their houses, and also forbidden to hang laundry outside to dry, which might have reminded people of crowded urban life. Today, however, it is almost impossible to find a Levittown house that has not been personalized and extended. See Gans (1967) for a description of early Levittown life.

5 For a fuller treatment of the complexities of connection in present-day suburbs, see Kolb (2008), and its companion website, www.dkolb.org/sprawlingplaces

6 Sometimes a social grammar of roles and actions imposes an already fully definite spatial layout on empty land, but even then the meaning of the patterns does not stay static over time. An example would be the north/south and east/west axes (the cardo and decumanus) of the classic Roman military camp, which met in a central space. These camps were erected all over the empire, and especially in Spain became the model for town planning, which was later exported for town planning all throughout Latin America, where the central square or zocalo shapes and is shaped by new patterns of life far beyond the original purposes.

7 See Castells (1996-98) for analyses of networked polycentric habits and patterns. Though Castells insists that a few mega-cities will continue to be the control centers for finance and innovation, he also points out that cities no longer serve as the centers for homogeneous geographical regions.

8 See Mitchell (2003) and Kolb (1992). Meanwhile evolutionary theory encourages a nonhierarchical polycentric vision of nature, even as the proponents of creationism and intelligent design fight to maintain a big Center and hierarchical mode of organization for nature, curricula and society.

9 There is the option of trying to anonymize one's electronic connections and traffic, but this is 
technically demanding and not available to everyone; anonymous traffic is a free rider on the average interactions. And it would be naive to think that the anonymizing sites do not have the ability to maintain their own panoptic archives. Brin (1998) argues that attempts to preserve privacy by forbidding surveillance tools would only insure that those tools are employed only by criminal organizations and shadowy governmental agencies. He urges that instead of banning such tools we remove the asymmetry from their uses, and open government and corporations to constant surveillance by anyone.

10 Physical space also imposes its own non-purposive restrictions and connections that resist being leveled out into a generic social matrix. My house sits next to that particular neighbor; my friend lives six miles away; the factory is inconveniently far; pollution upriver poisons these towns downstream; standard suburban layouts are disrupted by this wetland or that cliff.

11 Kolb (2002) discusses strategies, derived from the tendencies mentioned in its title, for critical awareness and conscious change within immersive artistic and entertainment media; similar strategies could also be applied to discern directions for change within totalizing architectural and cultural unities.

12 For striking examples of suburban reuse of dead malls and big boxes, see Dunham-Jones and Williamson (2008) and Dunham-Jones (2010).

\section{References}

Boden, D. and Molotch, H. (1994) 'The compulsion of proximity', in R. Friedland and D. Boden (eds) NowHere: Space, Time and Modernity. Berkeley: University of California Press.

Bourdieu, P. (1977) Outline of a Theory of Practice. Cambridge: Cambridge University Press.

Brin, D. (1998) The Transparent Society: Will Technology Force Us to Choose Between Privacy and Freedom. New York: Perseus Books.

Castells, M. (1996-98) The Information Age: Economy, Society and Culture. Oxford: Blackwell.

Castells, M. (2004) 'Afterword: why networks matter', Demos Collection, issue 20, pp. 219-225.

Dunham-Jones, E. (2010) 'Retrofitting suburbia'. Online video at: http://www.ted.com/talks/lang/eng/ ellen_dunham_jones_retrofitting_suburbia.html
Dunham-Jones, E. and Williamson, J. (2008) Retrofitting Suburbia: Urban Design Solutions for Redesigning Suburbia. New York: Wiley.

Fishman, R. (1997) 'Cities after the end of cities', Harvard Design Magazine, Winter/Spring, pp. 14-15.

Foucault, M. (1979) Discipline and Punish. New York: Random House.

Gans, H. (1967) The Levittowners: Ways of Life and Politics in a New Suburban Community. New York: Pantheon.

Hubbard, B. (2009) American Boundaries: The Nation, the States, the Rectangular Survey. Chicago: University of Chicago Press.

Kolb, D. (1992) 'Home on the range: planning and totality', Research in Phenomenology, pp. 3-1 1

Kolb, D. (2002) 'Hegelian Buddhist hypertextual media inhabitation, or, criticism in the age of electronic immersion', Bucknell Review 46(2), pp. 90-108.

Kolb, D. (2008) Sprawling Places. Athens, GA: University of Georgia Press. Available at: http:// www.dkolb.org/sprawlingplaces

Latour, B. (1998) 'Thought experiments in social science: from the social contract to virtual society', Brunel University, April. Available at: http:// www.artefaktum.hu/it/Latour.htm /accessed December 2010).

Latour, B. and Hermant, E. (2006) Paris: Invisible City. Available at: http://www.bruno-latour.fr/livres/ viii_paris-city-gb.pdf

Mitchell, W.J. (2003) Me+t: The Cyborg Self and the Nelworked City. Cambridge, Mass.: MIT Press.

Sassen, S. (1991) The Global City: New York, London, Tokyo. Princeton, NJ: Princeton University Press.

Slee, T. (2006) No One Makes You Shop at Wal-Mart: The Deception of Individual Choice. Los Angeles: Between the Lines Productions.

Sudjic, D. (1992) The 100 Mile City. New York: Harcourt.

David Kolb is Charles A. Dana Professor Emeritus of Philosophy at Bates College. His writings explore traditional vs. postmodern unities in philosophy, in architecture and urbanism, and in writing and scholarship. In these different areas new kinds of looser, linked and less centered unities emerge in thought, cities and in texts (see www.dkolb.org). Email: davkolb@gmail.com 